\title{
Blood glucose lowering efficacy of Avartaki Churna in Streptozotocin-induced
}

\section{Hyperglycemia in rats}

\section{Research article}

\author{
Guruprasad C Nille $^{1}$, Reddy KRC ${ }^{1 *}$, Anshuman Trigunayat ${ }^{2}$ \\ 1. Department of Rasa Shastra, Faculty of Ayurveda, \\ 2. Department of Pharmacology, Faculty of Medicine, \\ Institute of Medical Sciences, Banaras Hindu University, Varanasi, Uttar Pradesh, India
}

\begin{abstract}
Objective: To evaluate the hypoglycemic effect of A vartaki Churna (Cassia auriculata Linn.) in experimental animals. Materials and Methods: Avartaki Churna was prepared by the standard procedure of Churna Kalpana. Hyperglycemia was induced to create an equivalent to the diabetic state by giving streptozotocin (STZ) solution (intra-peritoneal [i.p.]) $35 \mathrm{mg} / \mathrm{kg}$. After assessment of hyperglycemia as an approximate induction of diabetes, Group IV animals were treated with $300 \mathrm{mg} / \mathrm{kg}$ of Avartaki Churna. For treatment comparison, Group III animals were treated with a standard hypoglycemic drug, glibenclamide $1 \mathrm{mg} / \mathrm{kg}$. Blood sugar level was assessed by glucometer on the $7^{\text {th }}, 14^{\text {th }}, 21^{\text {st }}$ and $28^{\text {th }}$ day. Results: Avartaki Churna produced a significantly reduction of fasting blood glucose with various doses in STZ-induced diabetic rats. In a 4-week study, Avartaki Churna produced a significant reduction in blood glucose compared to glibenclamide. Conclusion: A vartaki Churna and glibenclamide significantly reduced blood sugar level. The results were more significant with successive days in this in vivo comparative study.
\end{abstract}

Keywords : Avartaki Churna, Prameha, Streptozotocin

\section{Introduction}

In Ayurveda Prameha/Madhumeha can be considered as Diabetes Mellitus by different perspectives based on clinical symptoms and attempts have been made by Ayurvedic physicians and researchers to treat these two entities by using classical formulations mentioned in Prameha Chikitsa.(1) The first and most elaborated description of Avartaki in a classical text is available in Kaiyadeva Nighantu, where it's Pramehaghnal Madhumehaghna action through different botanical parts of plant has been mentioned. Kaiyadeva Nighantu is written by Kaiyadeva in $15^{\text {th }}$ century. According to Kaiyadeva Nighantu, the flower has Pramehashamana property. The tender fruits have been indicated as Sarvapramehahara. The seeds are said to be Madhumehaghna, and the root is used as Pramehaghna.(2)

Diabetes mellitus, a major lifestyle disease is undoubtedly the most challenging public health problem of 21 st century with a worldwide prevalence of 387 million (8.3\%) and predicted to be 592 million by $2035.77 \%$ of people with diabetes live in low- and middle-income countries. India, once known as the 'diabetes capital of the world' was home to 61.3 million patients with T2DM in 2011 with predictions of 101.2

*Corresponding Author:

KRC Reddy

Department of Rasa Shastra

Faculty of Ayurveda, IMS, BHU

Varanasi. U.P. 221005

Email: drkrcreddybhu@yahoo.co.in

Ph.No: +91-9415813533 million diabetics by 2030. India is second only to China which is home to 92.3 million diabetics.(3)(4)

\section{Materials and methods \\ Selection and Collection of Plant Materials:}

Avartaki (whole plant) was collected from the peripheral regions of Satara district, Maharashtra, India. The collected sample was pharmacogonostically identified and confirmed in Department of Dravyaguna, Faculty of Ayurveda, IMS, Banaras Hindu University, Varanasi.

\section{Churna Preparation}

The collected plant material of Avartaki Churna were cleaned and dried in the sunlight. The dried plant material was then ground into a fine powder using a mechanical pulverizer in Ayurvedic Pharmacy, Banaras Hindu University, Varanasi, India. This sample was used for anti-diabetic study.

\section{Chemicals}

Streptozotocin was sponsored by Department of Rasa-Shastra, Faculty of Ayurveda, IMS, BHU, Varanasi, which was purchased from Himedia Laboratories Pvt. Ltd. Dindori, Nashik, India. Batch number was 0000222052, manufacturing date was November 2014 and Expiry date is February 2017. Glibenclamide was purchased from Emcure SANOFI, trade name Daonil (Manufacturing date April 2015 and Expiry date 2016) in India, for use as the standard antidiabetic agent.

\section{Animals}

24 Charles Foster albino rats of either sex 
weighing between $180 \pm 30 \mathrm{~g}$ were used for the experimental study. The animals were obtained from the Central Animal House, Institute of Medical Sciences, Banaras Hindu University, Varanasi. The animals were freely allowed to eat pellet chow (Amrut Laboratory Animal Feed, Pranav Agro Industries Limited, Sangali) and ad libitum water during the study periods. Principles of laboratory animal care as per NIH guidelines were always followed and prior approval of Institutional Animal Ethical Committee (Reg. No.Dean/2014-15/EC/1057) of BHU was obtained before commencing experiments.(5)(6)

\section{Experimental Protocol}

The experimental study was conducted at the Department of Pharmacology, IMS, BHU. 24 animals were divided into four groups and were kept under standard laboratory condition during the study. The groups were named normal control (NC) (Group I), diabetic control (DC) non-treated (Group II), diabetic standard group (GB) (Group III) and the group of Avartaki Churna (AV300) (Group IV)

Before induction of hyperglycemia as an approximate induction of DM, the rats were kept fasting from all food; only water was given. Immediately prior to injection, STZ was dissolved in $50 \mathrm{mg}$ of sodium citrate buffer ( $\mathrm{pH} 4.5)$ to a final concentration of $1 \mathrm{mg} /$ $\mathrm{ml}$. The STZ solution was freshly prepared for each rat and was injected within $5 \mathrm{~min}$ after being dissolved. Hyperglycemia was induced (in-Group II to IV) by STZ solution intra-peritoneal (i.p.) using a dose of $35 \mathrm{mg} / \mathrm{kg}$ through insulin syringes. After $72 \mathrm{~h}$ blood sugar level was measured by Optimum Xceed glucometer (Abbott). For investigation of blood glucose, blood of rats was drawn through a tail central vein. Hyperglycemia was confirmed by the elevated glucose level in the blood by glucometer, determined after 72 h.(7) On the 7th day after confirmation of hyperglycemia, animals of Group IV were treated with Avartaki Churna. Animals of Group III were treated with hypoglycemic drug glibenclamide $1 \mathrm{mg} / \mathrm{kg}$. Glibenclamide stimulates the pancreatic beta cells of the pancreas and increasing the sensitivity of the peripheral tissue to insulin. Data of blood sugar was collected every 7 th day of duration for 4 weeks and compared among groups.

\section{Dose Schedule}

24 Charles Foster rats were divided into four groups, namely NC (Group I), DC (Group II), standard group treated with glibenclamide in dose of $1 \mathrm{mg} / \mathrm{kg}$ body weight (Group III) and treated group with Avartaki Churna (Group IV) in the dose of $300 \mathrm{mg} / \mathrm{kg}$ body weight. The test drug Avartaki Churna and standard drug glibenclamide were administered according to the body weight of the animal by oral route with the help of intragastric tube.

\section{Statistical Analysis}

Statistical analysis of data was performed using SPSS 16.0 and one-way analysis of variance. Results were expressed as mean \pm standard deviation from six rats in each group. $P<0.05$ was considered statistically significant and $<0.001$ were considered highly significant in the results of this study.

\section{Results}

The base line value in all four groups of albino rats showed that the fasting blood glucose (FBG) levels were within normal limits. The first task was to create an experimental model of hyperglycemia. A single dose (35 $\mathrm{mg} / \mathrm{kg}$ ) of STZ was administered to Groups II-IV, leaving Group I as an NC. Hyperglycemia was significantly induced compared to NC FBG after $72 \mathrm{~h}$ and was confirmed on the 7th day following STZ administration [Figure 1].

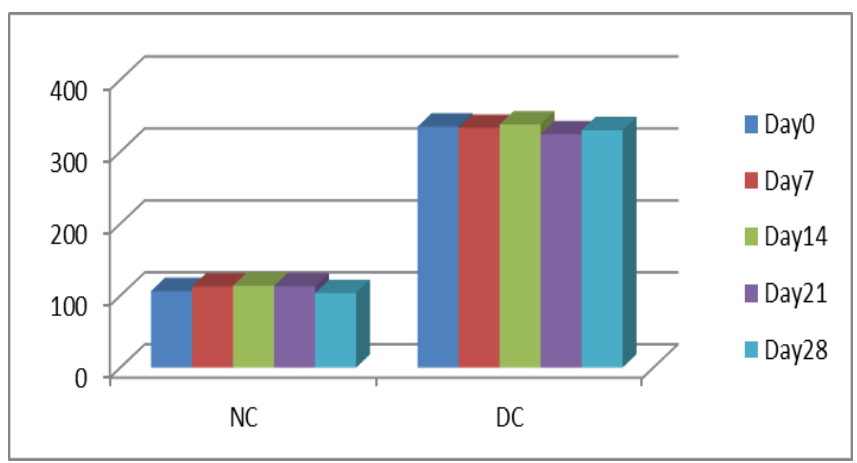

Figure 1: The effect on fasting blood sugar in streptozotocin-induced albino rats, where values are given as mean \pm standard deviation $(n=6$ in each group). Values are statistically significant at $P<0.05$,

$P<0.001$ compared with normal control group.

The second task was to evaluate dose-dependence on reduction in blood glucose of experimentallyhyperglycemic rats in our diabetic model. The stock solution was prepared freshly by adequate quantity of distilled water with the Avartaki Churna was given at the dose of $300 \mathrm{mg} / \mathrm{kg}$, to each of six rats in Group IV. Results are shown in Table 1, and demonstrated a dosedependent reduction, with $300 \mathrm{mg} / \mathrm{kg}$ showing the greatest reduction in blood glucose level. Avartaki Churna produced a maximum reduction of blood glucose of $\%(P<0.001) 1 \mathrm{~h}$ with dose of $300 \mathrm{mg} / \mathrm{kg}$. [Figure 2].

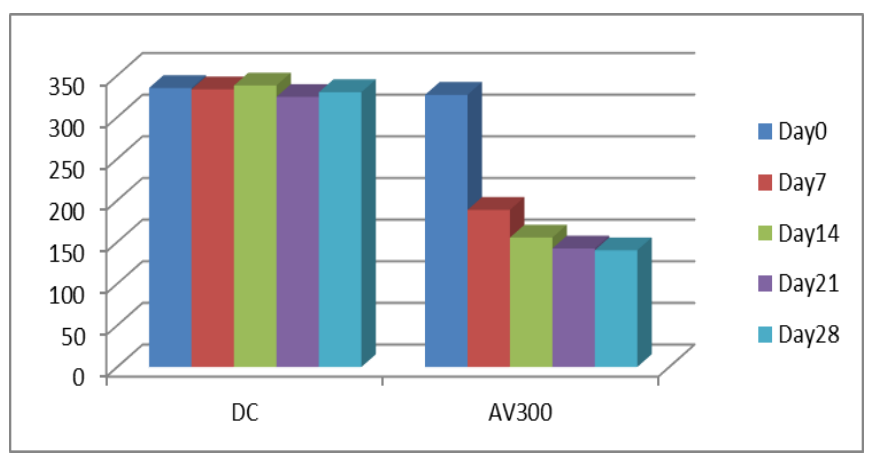

Figure 2: The effect of dose of Avartaki Churna on fasting blood sugar in streptozotocin-induced albino rats, where values are given as mean \pm standard deviation ( $n=6$ in each group). Values are statistically significant at $P<0.05, P<0.001$ compared with diabetic control group. 
The next task was to compare a dose of Avartaki Churna with a standard anti-diabetic drug, glibenclamide. In a 4-week study, Avartaki Churna produced a statistically highly significant reduction in blood glucose on day 7, compared to glibenclamide, as shown in Table 1. Glibenclamide $(1 \mathrm{mg} / \mathrm{kg})$ produced a maximum reduction of FBG $63 \%(1 \mathrm{~h}, P<0.001)$ compared to DC Group II.[Figure 3].

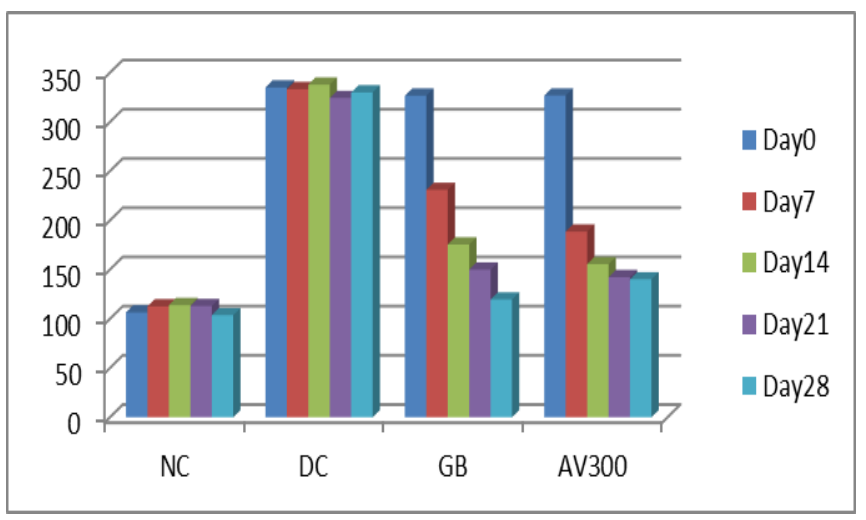

Figure 3: The effect of dose of Avartaki Churna and glibenclamide on fasting blood sugar in streptozotocininduced albino rats, where values are given as mean \pm standard deviation ( $n=6$ in each group). Values are statistically significant at $P<0.05, P<0.001$ compared with control group.

The results indicate a prolonged action in a reduction in blood glucose by Avartaki Churna and are probably mediated through enhanced secretion of insulin from $\beta$-cells of Langerhans or through an extrapancreatic mechanism. In the treated group for 4 weeks, significant reduction of FBG level was observed.

Mean and SD of sugar of normal group and various treatment groups on day $0,7,14,21$, and 28 was determined and show in Table 1. Mean sugar in NC group was much smaller as compare to other groups. Mean sugar level decreased successively on different days. The inter group comparison was statistically highly significant on each 7 th day observation. Post-hoc test for pair wise group comparison was also applied, and pairs were found statistically significant were shown in Table 1.

\section{Discussion}

Avartaki (Cassia auriculata Linn.) is a herbal drug mentioned elaborately in Kaiyadeva Nighantu with its Pramehaghna/Madhumehaghna properties. The same plant have also been studied in modern science and showed a significant reduction in blood glucose level in DM animal models by various mechanisms. Gupta et al. (2010) found Cassia auriculata Linn.leaf extract has insulinogenic action in streptozotocin-induced diabetic rats.(8) Latha et al. (2003) found Cassia auriculata Linn. flower extract suppresses enhanced gluconeogenesis and enhances utilization of glucose through increased glycolysis in streptozotocin-induced diabetic rats.(9) Abesundara et al. (2004) showed that Cassia auriculata Linn. flower extract exerts a strong antihyperglycemic effect in rats comparable to the therapeutic drug acarbose.(10) Venkatachalam et al. found that aqueous extract of flowers of Cassia auriculata Linn. has PTP1B inhibitory activity in Alloxan induced diabetic rats. (11) Brahmachari et al. showed that aqueous extract of whole plant of Casssia auriculata Linn.has hypoglycemic effect in STZ-induced diabetic rats.(12)

It is believed that the basis of the chemical constitution of different herbal drugs and various medicinal/plant extracts contain active flavonoids, alkaloids, phenolic compounds, terpenoids, saponins, and phytosterol type chemical constituents that are effective in the management of diabetic complications. This effect might be attributed to the amelioration of persistent hyperglycemia, oxidative stress, and modulations of the various metabolic pathway involved in the pathogenesis of diabetic complications.(13) The plant Avartaki (Cassia auriculata Linn) has number of phytochemicals in its various extracts of different botanical parts.(14)

In our study, Avartaki Churna showed a significant decrease in blood sugar level both compared to a

Table 1: Effect of Avartaki Churna on blood sugar level (mg/dl)

\begin{tabular}{|l|l|l|l|l|l|}
\hline Groups & Day 0 & Day 7 & Day 14 & Day 21 & Day 28 \\
\hline NC & $106.50 \pm 4.46$ & $112.67 \pm 5.164$ & $114.0 \pm 3.79$ & $113.0 \pm 4.14$ & $103.67 \pm 4.63$ \\
\hline DC & $335.0 \pm 23.62$ & $333.33 \pm 17.51$ & $338.0 \pm 10.04$ & $324.33 \pm 11.82$ & $330.0 \pm 16.44$ \\
\hline GB & $326.67 \pm 17.28$ & $231.0 \pm 26.79$ & $175.50 \pm 19.26$ & $150.0 \pm 10.19$ & $119.67 \pm 7.52$ \\
\hline AV300 & $326.83 \pm 21.86$ & $188.67 \pm 6.25$ & $155.50 \pm 15.57$ & $142.33 \pm 9.00$ & $140.17 \pm 4.49$ \\
\hline $\begin{array}{l}\text { One way } \\
\text { Anova }\end{array}$ & $\begin{array}{l}\mathrm{F}=220.51 \\
\mathrm{P}=0.000\end{array}$ & $\begin{array}{l}\mathrm{F}=186.47 \\
\mathrm{P}=0.000\end{array}$ & $\begin{array}{l}\mathrm{F}=317.67 \\
\mathrm{P}=0.000\end{array}$ & $\begin{array}{l}\mathrm{F}=645.74 \\
\mathrm{P}=0.000\end{array}$ & $\begin{array}{l}\mathrm{F}=724.23 \\
\mathrm{P}=0.000\end{array}$ \\
\hline Post Hoc & $\begin{array}{l}\text { (I II), (I III), } \\
\text { (I IV) }\end{array}$ & $\begin{array}{l}\text { (I II), (I III), } \\
\text { (I IV), (II III), (II } \\
\text { IV), (III IV) }\end{array}$ & $\begin{array}{l}\text { (I II), (I III), (II III), (II } \\
\text { IV), (III II) }\end{array}$ & $\begin{array}{l}\text { (I II),(I III), (II III), (II } \\
\text { IV), (III II) }\end{array}$ & $\begin{array}{l}\text { (I III), (II IV), (II } \\
\text { II), (III IV) }\end{array}$ \\
\hline
\end{tabular}

Values are given as mean $\pm \mathrm{SD}$ ( $n=6$ in each group). Values are statistically significant at $* P<0.05, * * * P<0.001$ compared with control group. NC: Normal control, DC: Diabetic control, GB: diabetic standard group (Glibenclamide treated), AV300: Avartaki Churna in 300 mg dose, SD: Standard deviation. 
diabetic non-treated control group and to a group treated with a standard anti-diabetic drug, glibenclamide in an animal model that replicated hyperglycemia. This study attempts to show that the mode of action of $A$ vartaki Churna may be similar to the mode of action of glibenclamide, i.e. by stimulating the pancreatic beta cells of the pancreas and increasing the sensitivity of the peripheral tissue to insulin. STZ causes selective destruction of insulin secreting beta cells and raised blood sugar level in animals.(15) STZ, N(methylnitrocarbon)-D-glucosamine is a potent methylatning agent for DNA and acts as nitric oxide donor in pancreatic $\beta$-cell and thus $\beta$-cells are more sensitive to damage by nitric oxide and free radical scavenging enzyme.(16)

\section{Conclusion:}

Avartaki Churna significantly decreases blood sugar level in experimental animals induced by STZ. Avartaki Churna reduced blood sugar level gradually. The results suggest a protective role of Avartaki Churna in STZ-induced hyperglycemia.

\section{References:}

1. Murthy ARV, Singh RH. Concept of Prameha/ Madhumeha (Contradictions and Compromises), Ancient Science of Life, October 1989, 9(2):71-9.

2. Sharma PV, Sharma GP, editor. Kaiyadeva Nighantu, $1^{\text {st }}$ ed., Varanasi:Chaukhambha Orientalia, 1979. p. 184.

3. International Diabetes Federation. IDF diabetes atlas. In: IDF, eds. A Book. 6th ed. Brussels, Belgium: International Diabetes Federation; 2013.

4. Kaveeshwar SA, Cornwall J. The current state of diabetes mellitus in India. Australas Med J, 2014;7:45-8.

5. Guide for the care and use of laboratory animals. NIH publication No. 85-23. Revised 1985

6. Hutchinson J. Researchers and animal protectionists: Creating a new partnership. Lab Anim 1985;9:37-39.
7. Kenneth $\mathrm{Wu}$, Youming Huan. Streptozotocin induce diabetic models in mice and rats. Current Protocol in Pharmacology. John Wiley \& Sons Inc. 2008.

8. Gupta S, Sharma SB, Singh UR, Bansal SK, Prabhu KM: Elucidation of mechanism of action of Cassia auriculata leaf extract for its antidiabetic activity in streptozotocin-induced diabetic rats, 2010, Journal of Medicinal Food; XIII(3):528-34.

9. Latha M, Pari L. Preventive effects of Cassia auriculata L. flowers on brain lipid peroxidation in rats treated with streptozotocin, 2003, Mol Cell Biochem; 243:23-28.

10. Abesundara KJ, Matsui T, Matsumoto K. Alphaglucosidase inhibitory activity of some Sri Lanka plant extracts, one of which, Cassia auriculata, exerts a strong antihyperglycemic effect in rats comparable to the therapeutic drug acarbose, 2004, J Agri Food Chem; 52: 2541-45

11. Venkatachalam M., Singaravelu G., Govindaraju K., Ahn Jong Seog, PTP 1B inhibitory action of a phytochemical propanoic acid, 2-(3-acetoxy-4,4,14 trimethylandrost-8-en-17-yl), 2013, Current Science, Vol.105; VI.

12. Brahmachari HD, Augusti KT. Hypoglycaemic agents from Indian indigenous plants, J. Pharm. Pharmacol. 1961 13: 381-85.

13. Singh R, Kaur N, Kishore L, Gupta GK. Management of diabetic complications: A chemical constituents based approach. J Ethnopharmacol 2013;150:51-70.

14. Nille et al. A Phytopharmacological Review of Plant - Cassia auriculata. International Journal of Pharmaceutical \& Biological Archives.2015;6(6):19.

15. Szkudelski T. The mechanism of alloxan and streptozotocin action in B cells of the rat pancreas. Physiol Res 2001;50:537-46.

16. Lukic ML, Stosic-Grujicic S, Shahin A. Effector mechanisms in low-dose streptozotocin-induced diabetes. Dev Immunol 1998;6:119-28. 